\title{
The Entrepreneurship Teaching of Sunan Kudus
}

\author{
Pujiyanto $^{1}$, Marhaeni Pudji Astuti ${ }^{2}$, Wasino $^{3}$, Cahyo Budi $\mathbf{U}^{4}$
}

\author{
${ }^{1}$ Social Science Education, Graduate School, Universitas Negeri Semarang \\ ${ }^{2}$ Sociology Department, Faculty of Social Sciences, Universitas Negeri Semarang \\ ${ }^{3}$ History Education Department, Faculty of Social Sciences, Universitas Negeri Semarang \\ ${ }^{4}$ History Education Department, Faculty of Social Sciences Universitas Negeri Semarang \\ ${ }^{1}$ Corresponding email: adjiepujiyanto70@gmail.com
}

\begin{abstract}
Wong Kudus is famous for its tenacity in trading. Their trading area expanded from all over Java in the era of Sunan Kudus. Now, Wong Kudus is trading all over the world. A remarkable achievement because there was born successful entrepreneurs in a small town like Kudus. This is certainly not a coincidence, but there is a tremendous trading passion that embodies the entrepreneurial values inherited from the prominent figure of the city, Kanjeng Sunan Kudus. The focus of this research is the entrepreneurship teachings of Sunan Kudus, toponym and gusjgang philosophy. This study used qualitative research method with phenomenological approach to know the views, knowledge, values, norms, rules existing in a society. The findings showed that Sunan Kudus teachings in the form of entrepreneurship teaching by leaving a trail of tradition dandangan and strong work ethic.
\end{abstract}

Keywords: Sunan Kudus, Entrepreneurship.

\section{Introduction}

In common parlance, being an entrepreneur is associated with starting a business, but this is a very loose application of a term that has a rich history and a much more significant meaning. The term "entrepreneur" originated in French economics as early as the 17th and 18th centuries. More specifically, it came to be used to identify the venturesome individuals who stimulated economic progress by finding new and better ways of doing things. The French economist most commonly credited with giving the term this particular meaning is Jean Baptiste Say. Writing around the turn of the $19^{\text {th }}$ century, Say put it this way, "The entrepreneur shifts economic resources out of an area of lower and into an area of higher productivity and greater yield." Entrepreneurs create value (Dees, 1998: 1).

Contemporary writers in management and business have presented a wide range of theories of entrepreneurship. Many of the leading thinkers remain true to the SaySchumpeter tradition while offering variations on the theme. For instance, in his attempt to get at what is special about entrepreneurs, Peter Drucker starts with Say's definition, but amplifies it to focus on opportunity. Drucker does not require entrepreneurs to cause change, but sees them as exploiting the opportunities that change (in technology, consumer preferences; therefore,cial norms, etc.) creates.
He says, "this defines entrepreneur and entrepreneurship - the entrepreneur always searches for change, responds to it, and exploits it as an opportunity." The notion of "opportunity" has come to be central to many current definitions of entrepreneurship. It is the way today's management theorists capture Say's notion of shifting resources to areas of higher yield. An opportunity, presumably, means an opportunity to create value in this way. Entrepreneurs have a mind-set that sees the possibilities rather than the problems created by change (Dees, 1998: 1).

The existence of the entrepreneurial spirit is largely influenced by 1) the environment of habitation, 2) occupation, 3) association, 4) and family. The famous entrepreneur, Nitisemito is the economic activist of Kudus City shaped by the vibrant municipal atmosphere of trade activities. The trading center is located in the Kliwon market and the Kudus market in West Kudus and also in smaller markets spread in many villages. The Kudus people are accustomed with trading world. The commerce actors are mostly committed by Javanese and the Chinese Muslims (the santri) (Wasino 2008: 42).

When Sunan Kudus initially began to explore the city, the livelihood of the population was trading. Trade among the community had grown rapidly. It was because of the distance from Demak and Jepara were not too far as those cities were the fairly busy 
trading center at that time (Wikantari, 1995: 51). During the reign of Mataram, the area around Kudus developed into a major rice supplier for Mataram. Towards the end of the 19th century, the public prosperity increased again due to the abundance of agricultural products. These crops became an important merchandise for the traders of Kudus. The home range of Kudus traders was also widespread though still limited in Java Island (Castles, 1982: 81).

The reliability of Kudus people in the world of commerce can be found in the writings of Lance Castles (Castle 1982: 81, and Clifford Geertz (Geertz 1977: 55). Both claimed that Kudus people have "accustomed" to trade from one city to another in Java Island. According to the belief, this trading skills of Kudus people had been inherited from Sunan Kudus as he was also excellent at trading. The truth should be proven since historically the people were not in coastal areas but they had "potential" trading skill, considering that they had interacted with the outsiders earlier. This phenomenon was in line with the existence of trading cities in that era (Tjandrasasmita, 2000: 45-104).

The success of santri's business in Kudus could not be separated from the prominent figure of the city, Sunan Kudus. The second teaching was trade or entrepreneurship as exemplified by Sunan Kudus who was also a merchant. Even if drawn to the line of the Holy Prophet Muhammad SAW, He was the Messenger and a merchant, then it is reasonable that Muslim scholars were also mostly merchants. In other words, trading is a hallmark of Muslims. Based on the field observations, the influence of the teachings of Sunan Kudus is still adhered to and live in the behavior of most of Kudus society until now.

\section{Methods}

This study used qualitative research method since there was a paradigm change in seeing the reality, phenomena, and symptoms.

The phenomenological approach is used knowing the opinions, knowledge, values, norms, rules existing in a society, and individual behavior or collectivity used as a guide to realize the behavior or action santri entrepeuneurship Kudus society.

\section{Results and Discussion}

\section{The entrepreneurship teaching of Sunan kudus.}

Trade and entrepreneurship were manifested in the form of dandangan tradition, Bubar market and two big markets named Kliwon market and Kudus Market. Both of Sunan Kudus' teachings are still believed by Kudus people until now. In order to trace and prove the truth of the teaching, a series of interviews were conducted so that later can be obtained the scientific truth and can be used as guidance to Kudus people.

Sunan Kudus was recognized as "Waliyul Ilmi", that was a religious leader but many people also recognized him as a merchant figure since he developed the economic life of Kudus society at that time. Castle in his writing divided Kudus City into two parts of West Kudus and East Kudus societies with various communities based on the citizens' ocupation. It is also mentioned about the life of markets in Kudus which illustrates how dynamic the trading life of santri society of Kudus.

In order to clarify the reader's understanding, the researchers divided Sunan Kudus' teachings into three main issues, that are the strategy of religious proselytizing, the toponyms of the villages around the Menara Kudus mosque, and the philosophy of Gusjigang. Those are discussed thoroughly at the following below in order to draw a conclusion, whether the entrepreneurship is authentically taught by Sunan Kudus to Kudus Society or not.

It was quite difficult to define what Sunan Kudus' teachings in a scientific explanation as there were very few (almost no written sources) materials such as documents, relics or possible things that could help the disclosure of scientific facts in this study. Many written books were published, even mostly written based on folklore or fairy tales / legends. Therefore, the researchers conducted a series of interviews with the central figure of the insiders of YM3SK (Menara Kudus Mosque Foundation and Tomb of Sunan Kudus) as the main source. Other sources were public figures and Muslim scholars of Kudus and cited some previous studies that were able to strengthen the analysis and series of stories.

Sunan Kudus was indeed a trader, besides 
an Islamic scholar. This can be proved by the existence of ceramics attached to the building of Menara Kudus mosque where the ceramic experts from Japan were from Champa. These ceramics show the symbol of wealth in his era. Sunan Kudus was also a timber expert based on the assumption that his father, Sunan Ngundung was from Cepu so that he was familiar with timber trade particularly teak "(Interview with Gus Najib, January 29, 2018).

At that time, every beginning of Ramadan, Sunan Kudus always announced to the people and then they came in flocks to Menara Kudus Mosque. Crowds of people poured into the streets surround the mosque so that many traders started to sale many merchandises there. That event became the first tradition which later was called dandangan, as an evidence that the trading activity in Kudus was already advanced. The market around Menara Kudus Mosque called Bubar market was extremely crowded till cover the area of Menara Kudus Mosque "(Interview with Gus Najib, January 29, 2018).

Explained that based on people's beliefs, the trading skill of Kudus people was mostly inherited from Sunan Kudus as he was also an excellent trader. We should examine the truth carefully, since historically the people in coastal areas do not have the potential to trade but they were initially interacted with the migrant community. This phenomenon corresponds to the existence of trading cities of that era (Tjandarsasmita, 2000: 45-104).

Sunan Kudus as Waliyyul Ilmu and also as "Wali Saudagar". As a wali sanga, Sunan Kudus has a business sense and high work ethic on himself as an abundant individual and the prosperity of the people he leads to be advanced. The great characters of Muslims in Kudus are having a high spirit in studying and having a reliable work ethic. In Said's terms, the sign of Suan Kudus as waliyul Ilmi gave birth to a "Muslim variant of santri ", and the sign as a rich Islamic holy man (wali saudagar) gave birth to "Islamic variant of santri merchant" (Said, 2010: 149).

Based on the explanation above, the researchers argue that the entrepreneurial teachings of Sunan Kudus exist. Here are some of the evidences,

1. Sunan Kudus is as both a Waliyul Ilmi and a wali saudagar.
2. The material riches of Sunan Kudus shows is the installation of ceramics in the Menara Kudus.

3. The economic activities to welcome the first day of fasting is in the form of the dandangan folk market which is started a month before fasting and ended in the first day of fasting, along the road of the Menara Kudus to the Alun-alun Kudus. Thus, it proves that Sunan Kudus was as the originator or initiator of the dandangan, it also proves that he was also an enterpreuneur at that time.

4. The santri saudagar variant raises the spirit of capitalism or religious spirit of religious capitalism with the background of cultural sub-culture Kudus Kulon or Sor Menoro by borrowing Said's term (2010) called bourgeois Islam or bourgeois santri ala Kudus Kulon.

5. The high wall in the houses of people in the Sunan Kudus surronding as a symbol of establishment in which there is luxury and grandeur of building and home contents and entrepreneurial activities. Unfortunately no one can show the location of Sunan Kudus' house until now.

Based on the data above, can be concluded that Sunan Kudus was taught the values of entrepreneurship that is reflected from 5 explanations above, Sunan Kudus gives birth Islam bourgeois generations, Islam developed the work ethic of resilient and reliable, thus borrowing Said's term (2010) they deserve the honour of being like the nobles.

\section{b. The Village Toponyms around Menara Kudus}

Toponym relates to the history of place names, it can be a city, village, or petilasan. Below are shown some toponyms of the village around the Sunan Kudus period. The villages in question are Kauman, Kajeksan, Langgar Dalem, Janggalan, Sunggingan, and Demangan Village. Damaran comes from the word Damaror firelighter. At that time student (santri) lived there needed damar when they want to get wudu at night because that place was quite far. That place now is well-known as Sucen Village located in the northeast of the tower mosque. It was called Damaran because at that time the life of Prince Pedamaran, 
descendants of the wali Kudus from Palembang grave (Mulkan, 1989: 65).

Kauman Village comes from the Arabic "qoum". People often call it qouman or Kauman. Kauman is the residence of the ulama and his santri, his territory is located around the tower of the Mosque. Kauman people often call themselves the "Sor Menoro" which means under the tower.

In addition; therefore,me areas' names in Kudus have their own meaning and long history, they are: Kauman Menara Village, Kajeksan Village, Langgar Dalem Village, Janggalan Village, Sunggingan Village, and Demangan Village. Kauman village comes from the Arabic "qoum". At the next stage of development, people then call it qouman or Kauman. Kauman is seen as the residence of the ulama and the religious, its territory around the Mosque tower. The name of Kajeksan Village comes from the word jeksa which means prosecutor. Formerly this area is a place to settle the prosecutors; therefore, then people call it Kajeksan. Langger Dalem was originally the home of Sunan Kudus. Dalem in Javanese means residence (home) or a title for a respected person, such as ngarso dalem is a title for king or sultan. Langgar means mushalla or mosque the place for worship; therefore, Langgar Dalem means mushalla Sunan Kudus. Janggalan comes from the word jenggala. In that area Mbah Jenggala live. The story of Mbah Jenggala among Kudus people is still confusing. Based on the stories, Mbah Jenggala would be suddenly and unexpectedly appeared when he was being talked. Mbah Jenggala in Javanese is known as Mak Jenggul (Indrahti, 2012: 48-49).

The name Demangan Village came from the word demang. Demat in the past was an office. At that time this place was the home of demangs; therefore, it was called demangan. In addition there was Kalinyamatan Village, where the followers of the Queen Kalinyamat who was located on the East Mosque Menara. The village of Paduraksan is related to the position of Sunan Kudus as a Kadhi in solving a problem or dispute. Sumur Tulak Village was a place to purify all objects with negative sense. Demakan Village was a residence of officials who may be officials of Demak. Jagalan was a slaughterhouse. Barongan village was a barong. Sayangan village was a place of settlement of the metal clerk located in the north of Mosque tower. Pekojan was a settlement of Koja
(Indian) people located in the east of the Gelis River. Pecinan as a settlement of the Chinese was located east of the Gelis River, Karetan Village was a place for the growth of rubber trees, and other names (Indrahti, 2012:48-49).

\section{c. Gusjigang}

Dandangan event is considered by some as the teachings of Sunan Kudus in terms of entrepreneurship and character of Kudus people who are kind and well-mannered, good trading skill, well-studied, then known as the character of Gusjigang.

Kudus is one of the coastal areas that has a unique cultural style. The Kudus society is a community of santri traders. They are adherents of puritanical Islam as exemplified by Sunan Kudus. Jigang's phrase which stands for Ngaji and Dagang gives the image of the Kudus people (Sardjono, 1997: 71). Gusjigang only partly upper middle businessmen and government officials, and traders of Kudus. Gusjigang is the self-image of the Kudus people (Sumintarsih, 2016: ix).

The Gusjigang philosophy taught by Sunan Kudus has been ingrained and characterized by the Kudus people to this day. Gusjigang character in practice is very reasonable because by trading people are able to reach the welfare of life in the world. However, prosperity in the world is not enough to lead to true happiness. The true happiness is happiness in the Hereafter. One of the ways to achieve true happiness is to continue to study, which is interpreted widely as an effort to demand and deepen knowledge. One of the results of demanding and deepening knowledge is the attitude and behavior of good or noble" (Maharromiyati, 2016: 18).

Sunan Kudus teaches the people of Kudus Gusjigang philosophy, as a spirit that must be maintained in order to improve the quality of self and economy as the provision of life. To be called as a wong Kudus (Kudus people), one must have good physical behavior and appearance, good looks, good attitude, and good behavior (Gus). This good behavior is then perfected by always studying ( $\mathrm{Ji})$, studying here is intended to seek knowledge and knowledge of both religious and scientific knowledge as provision of life and proved by trade experts (Gang), Jalil, 2013:258-259).

The opinions of Maharrohmiyati, Jalil, and idris that Gusjigang is a philosophy taught by Sunan Kudus according to the researcher is not correct. Researchers agree with Sumintasih who 
call Gusjigang as self image, and Said who call the stereotype of Kudus society (Said, 2010: 150) and ideal youth (Said, 2010: 127). According to researchers, the spirit of Gusjigang is derived from the teachings of Kanjeng Sunan Kudus, but Gusjigang appear later and not at the same time with Sunan Kudus. Therefore, Gusjigang exists in the Kudus society but not real or abstract. Gusjigang emerged later which is the stigma/ outsider view of the behavior patterns of the Kudus businessmen santri.

Nevertheless, the present-day Gusjigang spirit deserves to be actualized in a tangible form to support the building of the Kudus people. The santri traders who are wellbehaved, apparently, obedient to carry out religious teachings and those who work as successful traders. This is the spirit of trade based on the religious teachings held, which Said (2010) calls the spirit of religious capitalism, and Jalil (2013) Spiritual Entreupeneurship and researchers call it the work ethic of the santri Kudus.

Based on the explanation of 3 main ideas about Sunan Kudus teaching above can be summed up as follows:

1. Sunan Kudus is a merchant / trader wali

2. Sunan Kudus teaches trading and business activities as reflected in the toponyms of the villages in Kudus which indicate that in the time of the Sunan Kudus, the giving of the names of villages or places in the Kudus society has been shared in the work or business community.

3. Gusjigang is the crystallization of Sunan Kudus entrepreneurial values, although born or emerged later after the death of Sunan Kudus. Being the self-image or stigma of the Kudus people and the hope of the Kudus community towards their children and future daughters-inlaw.

\section{Conclusion}

Sunan Kudus teaches trading and business activities as reflected in the toponyms of the villages in Kudus which indicate that in the time of the Sunan Kudus, the giving of the names of villages or places in the Kudus society has been shared in the work or business community. Toponym is also a proof that describes the dynamics of economy and prosperity in the era of Sunan Kudus.
Gusjigang is a self-image, stereotype of the Kudus people, derived from their prominent figure that is Sunan Kudus but not as contemporaries when Gusjigang is manifested and implemented into a typical norm of wong Kudus.

\section{References}

Castle, L. (1982). Tingkah laku agama, Politik, dan Ekonomi di Jawa. 1982: Sinar Harapan Jakarta.

Dees, J. G. (October 31, 1998). Entrepreneur in Residence Kauffman Center for Entrepreneurial Leadership . J. Gregory Dees1 Entrepreneur in Residence Kauffman Center for Entrepreneurial Leadership Graduate School of Business Stanford University, 1.

Drucker, P. F. (1996). Inovasi dan Kewiraswastaan :Praktek dan DasarDasar (terjemahan). Jakarta : Erlangga.

Geertz. (1977). Penjaja dan Raja: Perubahan Sosial dan Modernisasi Ekonomi di Dua Kota di Indonesia. Jakarta: Buku Obor.

Geertz, C. (2013). Agama Jawa Abangan, Santri, Priyayi dalam Budaya Jawa. Depok: Pustaka Jaya.

Indrahti, S. (2012). Kudus dan islam : nilai-nilai budaya lokal dan industri wisata ziarah. Semarang: cv. Madina.

Mulkan, R. (1989). Bisnis Kaum Sufi. Yogyakarta: Pustaka Pelajar.

Said, N. (2010). Jejak Perjuangan Sunan Kudus dalam Membangun Karakter Bangsa. Bandung: Brillian Media Utama.

Said, N. (2013). Filosofi Menara Kudus Pesan Damai untuk Dunia. Kudus: Brillian Media Utama.

Sardjono, A. (1996). Rumah-rumah di Kota Lama Kudus. Yogyakarta: Tesis Program Pasca Sarjana UGM.

Tjandrasasmita, U. (2000). Pertumbuhan dan Perkembangan Kota-kota Muslim di Indonesia, dari abad XIII sampai XVIII Masehi. Kudus: Menara Kudus.

Wasino. (2008). Berjuang Menjadi Wirausahawan. Semarang: Unnes Press.

Wikantari, R. R. (1995). Safe Guarding A Lifing Heritage A Model for The Architectural Conservation of an Historic Islamic District of Kudus Indonesia. Tasmania: Thesis University of Tasmania. 